\title{
Romanesque and Gothic bricks from church in Pác - estimation of the firing temperature
}

IGoR ŠTUBŇA - Dpt. of Physics, Constantine the Philosopher University - istubna@ukf.sk

Rudolf PODOBA - Dpt. of Physics, Faculty of Civil Engineering, Slovak University of Technology

- rudolf.podoba@stuba.sk

Peter BAČíK - Department of Mineralogy and Petrology, Faculty of Natural Sciences,

Comenius University - bacik@fns.uniba.sk

L'uBoš PODOBNÍK - Dpt. of Physics, Constantine the Philosopher University - lubos.podobnik@ukf.sk

Érkezett: 2013. 01. 17. - Received: 17. 01. 2013. - http://dx.doi.org/10.14382/epitoanyag-jsbcm.2013.11

\section{Abstract}

Pavement bricks taken from the Romanesque and Gothic parts of the church in Pác, in the Trnava County, Slovakia, were investigated by XRD and thermal analyses DTA, TGA and TDA. It was found that the bricks contained dehydroxylated illitic clay, calcite, quartz and feldspar. As revealed, dehydroxylation was completely finished and no rehydroxylation was observed. The estimated firing temperature is between $650{ }^{\circ} \mathrm{C}$ and $700{ }^{\circ} \mathrm{C}$. Both bricks were made from local clay and very similar technologies were used.

Keywords: historical ceramics, thermal analysis, firing conditions

\section{Introduction}

Fired bricks, which are manufactured from $4500 \mathrm{BC}$, are more resistant to harsh weather conditions and much more reliable for use in permanent buildings than sun dried unfired bricks. During the $12^{\text {th }}$ century, fired bricks were reintroduced to Germany from Italy and brickmaking spread also to Hungarian Empire, as confirmed by discovered bricks in Romanesque churches [1, 2]. Investigation of the historic building ceramic objects, such as bricks and tiles, using the physical and chemical methods, helps us to understand the knowledge and skills used to produce them [3]. This is important in the renovation of historic buildings where damaged materials has to be replaced with new ones, with similar properties (e.g. color, texture) to the historic materials. To reveal the basic physical properties of historic building ceramics is beyond the capacity of standard archeological techniques. Therefore, we observe the exploitation of thermal analysis and other methods for better characterization of the archeological findings in the past 40 years (although the first uses of X-ray diffraction analysis (XRD) and differential thermal analysis (DTA) were 70 years ago [4]). Thermal analysis, especially DTA, thermogravimetric analysis (TGA) and thermodilatometric analysis (TDA) may be successfully applied to the study of historic building ceramics $[3,5,6,7]$.

The most frequent object of the thermoanalytical study of historic ceramics is the estimation of the firing temperature. The estimation is based on the comparison of the TGA, DTA and TDA curves measured on the historic ceramic samples with the curves measured on laboratory fired samples [5]. The last are known for the most probable constituents of ceramic clay such as kaolinite, illite, montmorillonite, muscovite, calcite, quartz and feldspar. These minerals will be decomposed and recrystallized, except for feldspar and quartz, if subjected to heating up to $950{ }^{\circ} \mathrm{C}$. This value is around the probable maximum temperature used for the firing of ancient ceramics. Very useful is XRD which helps to identify the presence or absence of these minerals in historic ceramics.

\begin{abstract}
2007. He is a senior research fellow at the Department Mineralosy and Petrology Comects University in Bratislava. The field of research: crystallography, crystal chemistry of silicates, phosphates and oxides, powder X-ray diffraction
\end{abstract}

Luboš PODOBNÍK Graduated from Constantine the Philosopher University (2011), major materials science. In the present, he is a PhD student at the Thermophysical Laboratory, Constantine the Philosopher University, Nitra. The field of research: Processes in illite-based and kaolin-based ceramics during firing, historical ceramics.

Every method used for the investigation of ancient ceramics, which exploits some kind of thermal analysis, is implicitly based on evaluation of the degree of conversion. It is known that most occurring phyllosilicates in historic ceramics (kaolinite, illite, montmorillonite, muscovite) change irreversibly if heated at a temperature which is within the interval of dehydroxylation of relevant phyllosilicate. Dehydroxylation of these minerals mostly occurs between $400^{\circ} \mathrm{C}$ and $600^{\circ} \mathrm{C}$. The upper limit depends on the rate of the heating and size of the fired body. Calcite decomposes according to $\mathrm{CaCO}_{3} \rightarrow \mathrm{CaO}+\mathrm{CO}_{2}$ if heated at the temperatures higher than $700^{\circ} \mathrm{C}$. Both processes, dehydroxylation and decomposition of calcite, are also influenced with a size of the particles, presence of impurities and other.

Dehydroxylation as a characterization of the historical ceramics is not reliable [7]. For example, we can observe dehydroxylation by the help of TGA or DTA if the historical ceramic body was fired at low temperature (e.g. $600^{\circ} \mathrm{C}$ ) for short time because dehydroxylation was not completed. If the firing temperature was higher (e.g. $700^{\circ} \mathrm{C}$ ) for sufficient long time, the dehydroxylation was completed. However, dehydroxylation can be also appeared in this case as a result of the escape of rehydroxylated water (originated from hydroxyl groups incorporated into dehydroxylated ceramics) if the historical ceramic body was in a contact with moisture for long time [8]. The products of dehydroxylation can not be considered as irreversible in a span of hundreds or thousands years between the firing and present analyses.

Contrary to dehydroxylation, decomposition of calcite is considered irreversible and a presence of calcite in historical 
ceramics is used as a marker for the firing temperature according to a rule „if the sample contains calcite, the firing temperature was below $800^{\circ} \mathrm{C}^{\prime \prime}$ [7].

The degree of conversion, which characterizes phase transformation of phyllosilicate or calcite during firing, depends on the temperature and time, $\alpha=\mathrm{f}(T, t)$, if measured on small powder sample. A different situation is in a large ceramic body such as a brick. Layers which are on the surface are transformed sooner than the layers inside the brick. Experiments on large cylindrical samples $(\varnothing 80 \mathrm{~mm})$ showed clear dependence of the degree of kaolinite $\rightarrow$ metakaolinite conversion on the location of the small sample taken for TGA. Consequently, $\alpha=\mathrm{f}(T, t, r)$, where $r$ is the distance of the sample from the axis of rotation. It was also found that after heating at $650^{\circ} \mathrm{C}$ for $10 \mathrm{~h}$ the degree of conversion reached $\sim 0.95$ and practically did not depend on $r[9,10]$.

In simple field kilns, which were used for firing bricks in the past, the fuel was beech wood [11]. Green bricks were prepared by molding the plastic mass made from local clay, silica sand or vegetal waste materials and water. Then the bricks were dried in a place protected again rain for several weeks and finally inserted into the kiln and fired. The firing process consisted from three steps. The first step was run at a low temperature to finish the removal of the physically bound water from pores. The second step was increasing the temperature up to the maximum determined by the technical capability of the kiln. As reported in [12, 13], the upper temperature limit in such a simple kiln is hardly higher than $700^{\circ} \mathrm{C}-720^{\circ} \mathrm{C}$. The third step was slow cooling. The whole firing cycle took $\sim 7$ days in a small field kiln. We can assume that a similar method and equipment were used for firing the bricks of the Romanesque church in Pác sometime in the $13^{\text {th }}$ century. The same we can assume for a Gothic period brickmaking because it did not significantly changed up to industrial revolution [14].

In this paper, the study is focused on the analysis of the bricks from the church in Pác. Our goal was to estimate the firing temperature.

\section{Experimental}

The samples were old pavement bricks from the church of St. Peter and Paul located in Pác, Trnava County, Slovakia. The church was originally built in the Romanesque style, was later rebuilt in the Gothic style in $15^{\text {th }}$ century and enlarged in the Baroque style in $17^{\text {th }}$ century. The pavement bricks come from the Romanesque and Gothic parts of the church. Romanesque pavement was later overlaid with Gothic pavement, overlaid with Baroque pavement. Both pavement bricks, Romanesque and Gothic, were directly in the open air for $\sim 300$ years.

The DTA and TGA were performed on the modernized Derivatograph $1000^{\circ}$ (MOM, Hungary) [15] using compact samples of $10 \times 10 \times 20 \mathrm{~mm}$ cut from the bricks and a heating rate of $5{ }^{\circ} \mathrm{C} / \mathrm{min}$. A reference compact sample of the same size was made from a pressed powder $\mathrm{Al}_{2} \mathrm{O}_{3}$. The TDA was done on the dilatometer described in [16] with the sample $10 \times 10 \times 40$ $\mathrm{mm}$ at the heating rate $5^{\circ} \mathrm{C} / \mathrm{min}$.

The phase analysis was performed using the Powder X-ray diffraction on the diffractometer BRUKER D8 Advance under following conditions: Bragg-Brentano geometry (Theta2Theta), $\mathrm{Cu}$ anticathode $\left(\lambda \alpha_{1}=1.54060 \AA\right)$, accelerating voltage $40 \mathrm{kV}$, beam current $40 \mathrm{~mA}$. Ni K $\beta$ filters was used for stripping of $K \beta$ radiation on the primary and diffracted beam, and data was obtained by the BRUKER LynxEye detector. The step size was $0.01^{\circ} 2 \Theta$, the step time was $1 \mathrm{~s}$ per one step, and the range of measurement was $2-65^{\circ} 2 \Theta$. Measured data were evaluated with DIFFRAC ${ }^{\text {plus }}$ EVA software package using ICDD PDF-4+ database and Rietveld refinement with DIFFRAC ${ }^{\text {plus }}$ TOPAS was used for verification of identified phases.

\section{Results and discussion}

The results of XRD analysis of the bricks are illustrated in Fig. 1. Here, reflections of the four minerals are seen. Feldspar does not change its structure at the firing temperatures lesser than $950{ }^{\circ} \mathrm{C}$ and quartz transforms its structure at $573{ }^{\circ} \mathrm{C}$ reversibly. Thus the feldspar and quartz reflections can be considered the same as for the green bricks. Calcite is also present in the bricks, which shows that the firing conditions were not sufficient for its full decomposition. XRD reflections of illite were also found which also confirms lower firing temperature. The XRD patterns for the Romanesque and Gothic bricks are almost identical except a relatively small difference in quantitative proportions of albite and orthoclase feldspars (ca. 5\%; based on the Rietveld refinement results). We can state, that clay for both bricks was dug in the very close places and the firing technologies were very similar.

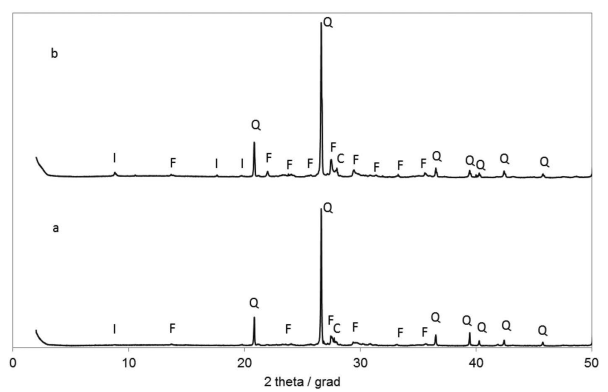

\footnotetext{
Fig. 1. XRD patterns of the Romanesque brick and Gothic brick. $Q-q u a r t z$, $F$ - feldspar, $C$ - calcite, I - illite/muscovite

1. ábra Röntgendiffraktogramok (a) római kori tégla és (b) gótikus kori tégla.
} Q-kvarc, F-földpát, C-kalcit, I - illit, muszkovit

The results of DTA and TGA are illustrated in Fig. 2 and Fig. 3. The first endothermic minimum on the DTA curves, which belongs to the interval of $20-300^{\circ} \mathrm{C}$, is typical for porous building clay ceramics, which do not contain a glassy phase, i.e. fired at a relatively low temperature. The minimum is related to the liberation of the physically bound water absorbed on the surface of the mineral grains. It is known that the porosity of the green clay increases, for example porosity of the green porcelain mixture increases $4-5 \%$ during dehydroxylation [ 17 , 18]. In spite of the higher porosity, dehydroxylated ceramic body can absorb less water molecules than the green body. This can be explained by improved mechanical strength of the samples after dehydroxylation and less capability of the dehydroxylated samples to expand. This was observed on different green ceramic mixtures including illitic clay from a vicinity of the church [19].

The second step of the mass loss has sharp termination at $\sim 840^{\circ} \mathrm{C}$ which is a typical feature of the TGA curve of calcite decomposition [20]. Between these two significant mass losses, a gradual mass loss is present which can be explained by the presence of the dissociated water molecules, i.e. ions $\mathrm{H}^{+}$and $\mathrm{OH}^{-}$on the crystal surfaces. To liberate such water, higher temperature (up to $600^{\circ} \mathrm{C}$ ) is necessary [21]. The second reason can be the liberation of $\mathrm{OH}^{-}$which could insert itself into dehydroxylated clay during rehydroxylation. For 
example, a measurable rehydroxylation was registered in $19^{\text {th }}$ century bricks [8]. Neither the endothermic minimum on the DTA curve (Fig. 2) nor a clear step of mass loss on the TGA curve (Fig. 3), which could be ascribed to the intensive second dehydroxylation, were registered with these analyses. Rehydroxylation is very slow process [8] and 200 years, when the bricks were in the open air, was probably not sufficiently long time for the binding of greater amount of $\mathrm{OH}^{-}$into dehydroxylated clay structure. After that period, the new plaster and pavement were laid onto the bricks, therefore the bricks were protected from atmospheric moisture up to now.

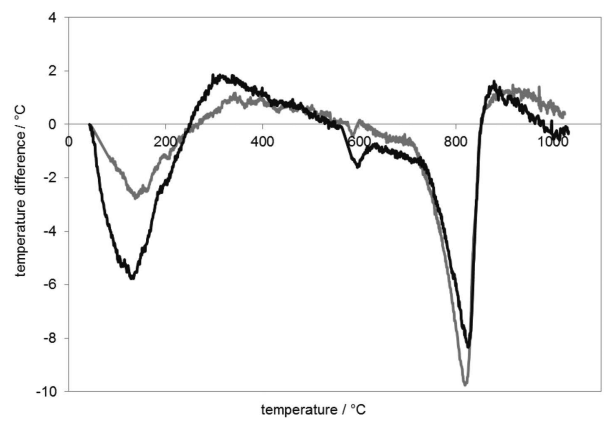

Fig. 2. Differential thermal analysis of the Gothic (gray) and Romanesque brick (black)

2. ábra Római kori tégla (fekete) és gótikus kori tégla (szürke) DTA görbéi

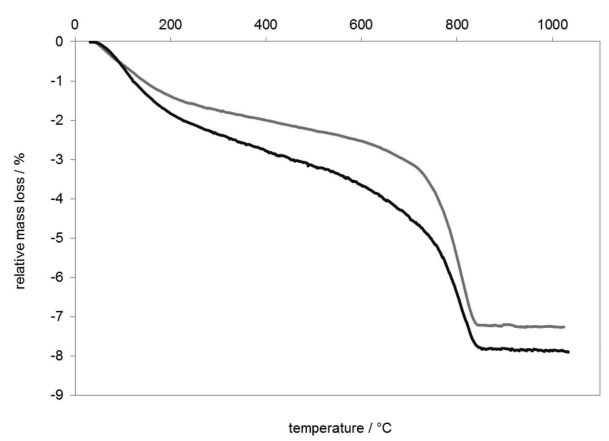

Fig. 3. Thermogravimetry of the Gothic (gray) and Romanesque brick (black)

3. ábra Római kori tégla (fekete) és gótikus kori tégla (szürke) TG görbéi

The results of TDA are visualized in Fig. 4. The TDA of the both bricks showed the presence of significant amount of quartz, which corresponds with a small DTA endothermic peak at $\sim 570^{\circ} \mathrm{C}$. Above $700^{\circ} \mathrm{C}$, the TDA curves of the brick material begin to bend downwards, i.e. contraction of the sample takes place. It can be ascribed to decomposition of calcite [22]. After completion of this decomposition, the samples continue to expand up to the maximum experimental temperature $1000^{\circ} \mathrm{C}$. If the glassy phase is present in the bricks, it would be indicated on both TDA curves via typical contraction caused by the pressing force of the dilatometer's push-rod [23]. This contraction appears above transformation temperature of the glassy phase. Since the glassy phase can arise during firing at the temperatures higher than $\sim 800^{\circ} \mathrm{C}[4]$, we can state, that the maximum firing temperature of the both bricks was lower than $800^{\circ} \mathrm{C}$.

Both TDA curves depicted in Fig. 4 can be used for estimation of the firing temperature $[4,24,25]$. The thermal expansion method is based on the fact that when the partially fired clay body is subjected to a linear heating during TDA, shrinkage occurs above a certain temperature. The point on the dilatometric curve where contraction starts is considered the original firing temperature. According to this rule, the temperature $\sim 720^{\circ} \mathrm{C}$, which corresponds to the beginning of the contraction, is the firing temperature for the both bricks. This contraction is caused by the decomposition of calcite which is accompanied with significant shrinkage $[22,23]$.

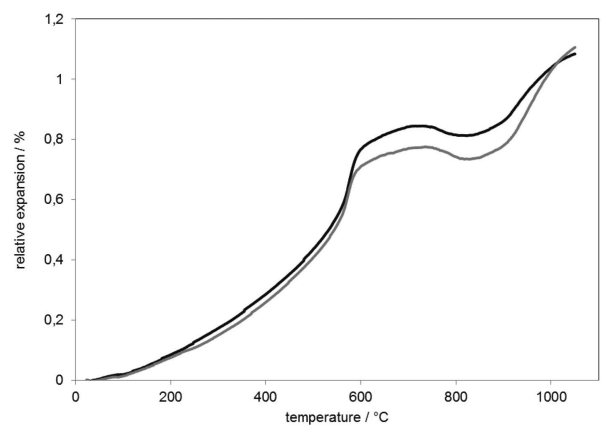

Fig. 4. Thermodilatometry of the Gothic (gray) and Romanesque brick (black)

4. ábra Római kori tégla (fekete) és gótikus kori tégla (szürke) termodilatometriai görbéi

If we suppose a firing schedule according to Fig. 5, we see that a period with temperatures higher than $450^{\circ} \mathrm{C}$, which are suitable for dehydroxylation, is $\sim 60 \mathrm{~h}$ long for 7-day firing. The period at $700^{\circ} \mathrm{C}$, where dehydroxylation runs very intensively, is also sufficiently long: $\sim 35 \mathrm{~h}$. In a case of the shorter isothermal heating, we have a period of $48 \mathrm{~h}$ with temperatures above $450^{\circ} \mathrm{C}$. That are sufficient times for completing dehydroxylation in a large body such as a brick.

As written above, the estimation of the firing temperature is based on the evaluation of the degree of transformation. Irreversible phase transformations, which we took into account, were dehydroxylation of phyllosicates and decomposition of calcite. A formation of a glassy phase is beyond the capability of the simple medieval kiln (heated with wood) which was supposedly used for the firing of bricks. Vitrification temperature of clays is higher than $700^{\circ} \mathrm{C}$, mostly above $800^{\circ} \mathrm{C}$ [4]. As mentioned above, the degree of conversion depends on the temperature and time, i.e. the same degree of conversion we can obtain with lower temperature (which is from an interval of the relevant transformation) and longer time or with higher temperature and shorter time. But an influence of the temperature is stronger than the influence of the firing duration. These conditions results in a leftover amount of the dehydroxylated phyllosicates and calcite after firing (i.e. the degree of conversion), and consequently, the results obtained by the used method (TGA, DTA, TDA and XRD). Therefore, if we want to estimate the firing temperature, we should know a firing schedule. If the firing at high temperatures takes sufficient time, these reactions can be completed in the whole brick's volume. After analysis of the possible firing schedule (Fig. 5), we can conclude that there was enough time to complete dehydroxylation in the whole brick's volume at temperatures higher than $600^{\circ} \mathrm{C}$ during minimally $35 \mathrm{~h}$. We can say that the minimum firing temperature was $\sim 600^{\circ} \mathrm{C}$. On the other side, the firing conditions were not sufficient for the total decomposition of calcite. The upper limit of the firing temperature can not be estimated from the decomposition of calcite only which expresses itself in Figs. 2 and 3 by the mass loss and endothermic minimum and by a contraction in Fig. 4. 
Besides that, we should take into consideration the technical limit of the kiln. It was probably not higher than $700^{\circ} \mathrm{C}$.

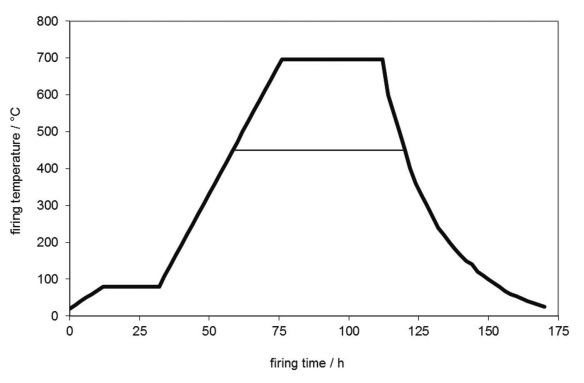

Fig. 5. The assumed firing schedule for 7-day firing with two different coolings

5. ábra Feltételezett égetési program a 7 napos égetés során. A $450^{\circ} \mathrm{C}$ feletti hömérséklet elégséges a vízvesztéshez

\section{Conclusions}

Pavement bricks taken from a Romanesque and Gothic parts of the church in Pác in the Trnava County, Slovakia were investigated by XRD and thermal analyses DTA, TGA and TDA. It was found that the bricks contained dehydroxylated illitic clay, calcite and quartz. As revealed, dehydroxylation was completely finished and no significant rehydroxylation was observed. Decomposition of calcite was also observed. The estimated firing temperature is between $650^{\circ} \mathrm{C}$ and $700{ }^{\circ} \mathrm{C}$.

Both bricks were made from the local clay pits and very similar technologies were used in spite of the $\sim 300$ year time interval between their productions.

\section{Acknowledgements}

This work was supported by the grant VEGA 1/0646/12, Ministry of Education of Slovakia. One author (I.Š.) is indebted to prof. V.A. Drebuschchak (Novosibirsk State University, Russia) for his interest in our work and valuable comments.

\section{References}

[1] Kristály, F. - Kelemen, É. - Rózsa, P. - Nyilas, I. - Papp, I.: Mineralogical investigations of medieval brick samples from Békés county (SE Hungary). Archaeometry, 54 (2012) 250-266,

http://dx.doi.org/10.1111/j.1475-4754.2011.00628.x

[2] Podolinský, Š.: Cultural beauties of Slovakia, Romanesque churches. Dajama, Bratislava 2009 (in Slovakian)

[3] Vandiver, P.: The role of materials research in ceramics and archeology. Annual Review of Materials Research, 31, (2001) 373-385 http://dx.doi.org/10.1146/annurev.matsci.31.1.373

[4] Tite, M.S.: Determination of the firing temperature of ancient ceramics by measurement of thermal expansion: a reassessment. Archaeometry, 11 (1969) 131-143, http://dx.doi.org/10.1111/j.1475-4754.1969.tb00636.x

[5] Drebuschchak, V.A. - Mylnikova, L.N. - Drebuschchak, T.N.: The massloss diagram for the ancient ceramics. J. Thermal Analysis and Calorimetry, 104 (2011) 459-466, http://dx.doi.org/10.1007/s10973-010-1230-x

[6] Drebuschchak, V.A. - Mylnikova, L.N. - Molodin, V.I.: Thermogravimetric investigation of ancient ceramics. J. Thermal Analysis and Calorimetry, 90 (2007) 73-79, http://dx.doi.org/10.1007/s10973-007-8478-9

[7] Drebuschchak, V.A. - Mylnikova, L.N. - Drebuschchak, T.N. - Boldyrev, V.V.: The investigation of ancient pottery - Application of thermal analysis. J. Thermal Analysis and Calorimetry , 82 (2005) 617-626, http://dx.doi.org/10.1007/s10973-005-6913-3

[8] Hamilton, A. - Hall, C.: A review of rehydroxylation in fired-clay ceramics. J. American Ceramic Society, 95 (2012) 2673-2678, http://dx.doi.org/10.1111/j.1551-2916.2012.05298.x
[9] Ondruška, J. - Trník, A. - Vozár, L.: Degree of conversion of dehydroxylation in a large electroceramic body. Int. J. Thermophysics, 32, (2011) 729735, http://dx.doi.org/10.1007/s10765-010-0899-1

[10] Ondruška, J. - Trník, A. - Medved', I.: Estimation of mass transfer parameters during dehydroxylation in a large ceramic body by inverse methods. Ceramics International, 37, 2011, 3299-3305, http://dx.doi.org/10.1016/j.ceramint.2011.05.126

[11] Kováč, F.: The firing of bricks in field kilns. Dom techniky, Bratislava 1960 (in Slovakian)

[12] Road map for cleaner brick production in India. Research report, Greentech Knowledge Solution, New Delhi, India, 2012

[13] A study of a brick-making process along the Texas portion of the U.S.-Mexico border: Senate bill 749. Report, Texas Commission on Environmental Quality, Austin 2002

[14] Laefer, D.F. - Boggs, J. - Cooper, N.: Engineering properties of historic brick - variability considerations as a function of stationary versus nonstationary kiln type. Journal of the American Institute of Conservation of Historic and Artistic Works, 4 (2004) 255-272

[15] Podoba, R. - Trník, A. - Podobník, L.: The upgrating of TGA/DTA analyzer Derivatograph. Epitoanyag - Journal of Silicate Based and Composite Materials, 64 (2012) 28-29

[16] Štubňa, I. - Vážanová, A. - Varga, G. - Hrubý, D.: Simple push-rod dilatometer for dilatometry of ceramics. In: Proc. Conf. Research and Teaching of Physics, SPU Nitra, Nitra 2007, 69-74

[17] Štubňa, I. - Kozík, T.: Permeability of the electroceramics to gas and its dependence on the firing temperature. Ceramics International, 23 (1997) 247249, http://dx.doi.org/10.1016/S0272-8842(96)00034-X

[18] Plešingerová, B. - Súčik, G. - Fabián, M.: Surface area change of kaolin causing annealing. Acta Metallurgica Slovaca, 17 (2011) 169-176

[19] Podobník, L. - Jankula M. - Štubňa, I.: Influence of dehydroxylation on hydration of illitic and kaolinitic clays. XXV DIDMATTECH 2012, Book of Abstracts, JSU Komárno, 2012, 20-21

[20] Teleki, A. - Vozár, L. - Tóth, A.: Kinetics of the irreversible chemical process. In: Cophys - International Physics Workshop, UKF Nitra, Nitra 2008, 99107 (in Slovakian)

[21] Kiselev, I.M.: Firing of kaolin and investigation of fired products. $\mathrm{PhD}$ thesis stored in ONIITECHIM, Čerkassy, 1978, No. 1762178 (in Russian)

[22] Tóth, A.: Physical properties of lime before and after firing. PhD thesis, UKF Nitra, Nitra 2009 (in Slovakian)

[23] Ventureli, C. - Paganelli, M.: Sintering behavior of clays for the production of ceramics. Cfi/Ber. DKG, 84, (2007) N5, E1-E3

[24] Roberts, J.P.: Determination of the firing temperature of ancient ceramics by measurement of thermal expansion. Archaeometry, 6 (1963) 21-23, http:// dx.doi.org/10.1111/j.1475-4754.1963.tb00574.x

[25] Petrovič S. - Jovanov, V. - Vujovič, S. - Ranogajec. J.: Historical materials from the medieval fortress Bač. Processing and Application of Ceramics, 1 (2007) 75-80, http://dx.doi.org/10.2298/PAC0702075P

Ref.:

Igor Štubňa - Rudolf Podoba - Peter Bačík - Luboš Podobník: Romanesque and Gothic bricks from church in Pác - estimation of the firing temperature

Építőanyag, 65. évf. 2. szám (2013), 48-51. p.

http://dx.doi.org/10.14382/epitoanyag-jsbcm.2013.11

\section{Római és gótikus kori téglák Pác templomából}

- Az égetési hőmérséklet becslése

Pác (Trnava megye, Szlovákia) templomának anyagából vett római kori és gótikus kori tégla mintákon végeztünk röntgendiffrakciós (XRD) és termoanalitikai (DTA, TGA, TDA) vizsgálatokat. A vizsgálatok a téglák anyagában kristályvízmentes illit agyagásványt, kalcitot, kvarcot és földpátot mutattak ki. Bebizonyosodott, hogy az illit vízvesztése teljes mértékben lejátszódott, és utólagos kristályvíz beépülés nem volt kimutatható. Az égetési hômérséklet becsült értéke $650^{\circ} \mathrm{C}$ és $700^{\circ} \mathrm{C}$ közé tehetô. Mindkét tégla helyi agyag felhasználásával készült nagyon hasonló technológiával.

Kulcsszavak: történeti kerámiák, termikus vizsgálat, égetési körülmények 